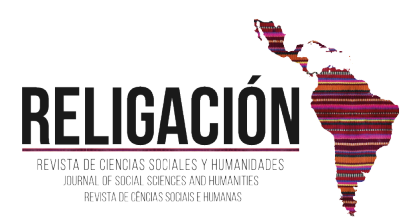

Sección General

\title{
Electronic educational resources in the process training
}

Recursos educativos electrónicos en el proceso de formación

\author{
Liliya A. Meteleva | Togliatty State University - RUSSIA | \\ Togliatti State University, Russian Federation, 445020, Togliatti, Belorusskaya str., 14 E-mail: marsela_I.m@bk.ru \\ K. Shankar | Kalasalingam Academy of Research and Education - INDIA | \\ School of Computing, Kalasalingam Academy of Research and Education, Krishnankoil, India. E-mail: shankar.k@klu.ac.in \\ B. Ayshwarya | Kristu Jayanti College - INDIA | \\ Department of Computer Science, Kristu Jayanti College, Bangalore-560043, India.
}

\begin{abstract}
The aim of the article is to analyze the possibilities of using the electronic educational and methodological complex in the process of students' professional training. A new educational paradigm should provide mobility, flexibility, expansion of horizons for all possible learning paths. The processes of globalization show that the formation of the information society, and at the same time the "information-educated" one, is occurring at a very fast pace. At all levels of education, information and communication technologies (ICT) have become the basis for the organization of the educational process. Education in agriculture is no exception. Moreover, experience shows that technological training of students will be of higher quality if it is carried out through the use of ICT.
\end{abstract}

Keywords: Electronic educational resource, information society, education, vocational training.

RESUME: El objetivo del artículo es analizar las posibilidades de utilizar el complejo electrónico educativo y metodológico en el proceso de formación profesional de los estudiantes. Un nuevo paradigma educativo debería proporcionar movilidad, flexibilidad, expansión de horizontes para todos los caminos de aprendizaje posibles. Los procesos de globalización muestran que la formación de la sociedad de la información y, al mismo tiempo, la «educada en la información», está ocurriendo a un ritmo muy rápido. En todos los niveles de educación, las tecnologías de la información y la comunicación (TIC) se han convertido en la base para la organización del proceso educativo. La educación en agricultura no es la excepción. Además, la experiencia muestra que la formación tecnológica de los estudiantes será de mayor calidad si se lleva a cabo mediante el uso de las TIC.

Palabras clave: recurso educativo electrónico, sociedad de la información, educación, formación profesional. 


\section{INTRODUCTION}

The use of electronic educational resources - EER - serves as a positive trend in education. The use of distance learning methods is important for a faster and more complete transfer of knowledge and information from the teacher to the students. The student is given the opportunity to independently choose the time to complete the tasks, which gives him an advantage in studying various disciplines, including the choice. However, the issues of completeness of understanding and assimilation of knowledge remain poorly studied, because distance learning does not allow to transfer and feel all aspects of acquired professional knowledge.

Electronic educational resources are a relatively recent phenomenon in the educational process. However, this topic requires a more detailed study in the course of various trends, concepts and trends in the development of the modern education system.

Researchers Amirov N.I., Ruziboev U., Grachikova Yu.V., Levin MV, Sosenushkin S.E. developed the necessary requirements for modern electronic educational resources. For a more successful mass application of EER, it is first necessary to determine and develop uniform requirements for electronic resources before a practical result is obtained.

Korolev D.A., Bulatov A.A., Komkov R.V., Kochisov V.K., Gogitsaeva O.U., Timoshkina N.V. considered the electronic educational resource as a new pedagogical tool in the context of the development of interdisciplinary connections. The study of interdisciplinary connections is now becoming an increasingly important pedagogical task.

Mokhova S.Yu., Stepanova T.Yu., EERurzaeva Zh.B. consider these issues on the basis of the psychological aspects of the implementation of electronic educational resources.

Stepanova T.Yu., EERurzaeva Z.B., Vasilyev V.L., Gapsalamov A.R., Khafizova N.Yu., Krivolapova EV, Sufiha R. explored this issue as a means of increasing the cognitive activity of students.

Morozov A.V., Samborska L.N. proposed to apply the EER to educate children with disabilities, which, in their opinion, would play a positive role in the employment of persons with disabilities.

Zagrebina S.A., Ilyin A.G. suggest using the method of interactive cinema as an electronic educational resource in teaching cultural disciplines in high school.

\section{METHODOLOGY}

This article uses the methods of content analysis, allowing to study the relevant literature on this topic. The method of system-structural analysis of the main modern terms and concepts allows us to more accurately understand their applicability in the framework of the study. The method of systematization of the results allowed to summarize the results of the study and draw the appropriate conclusions. The synergetic approach in this study allowed us to consider the organization of electronic educational resources of learning through the prism of systematic and self-organizing activities of an individual in the framework of social and professional activities.

\section{RESULTS}

The results of the study suggest the need to introduce mechanisms for distance approach in training. The article gives the main theoretical recommendations on the use of electronic educational resources in distance education, which allow the teacher to act more confidently and rationally use their strength to prepare for new classes.

The practical applicability of this work lies in the fact that its results can be applied in the further development of this problem in the use of electronic educational resources in teaching, as well as in the practical use of basic recommendations in distance learning.

At present, it is advisable to solve the tasks at the present stage using an integrated approach - the introduction of innovations in general and, especially, in the field of higher professional education (Khafizova, 2018) (Ivygina, 2018). In particular, within the framework of the formation of students' information and technological competence, we suggest that technologically advanced students work with electronic educational resources. Such an approach makes it possible to master the theoretical foundations of the topic under study, select basic patterns for their experimental verification, and conduct virtual computer experiments.

To actively introduce the competence approach in the educational process and increase its efficiency, it is necessary to develop innovative elements of educational and methodological support based on information technol- 
ogies (Stepanova, 2015).

Obviously, the traditional methods of teaching students are ineffective in this approach. Information training is an individual process; therefore, the organization of the educational process acquires much greater efficiency using electronic educational resources (EER) and a creative workshop. At the same time, it is worth noting that traditional gaming technologies continue to play an important role in the educational process.

Special attention should be paid to the last type of EER, since the use of games in training has become particularly relevant with the development of information technology. As a result, the use of gaming-type electronic educational resources (EER) in the educational process, combining the advantages of gaming and modern information and communication technology (ICT) capabilities, is gaining popularity. The electronic educational resource of a gaming type is an educational material, for reproduction of which electronic devices are used, intended to create learning situations that implement the activities of students in a playful way (Grachikova, 2015: p.45).

An electronic educational resource is a program-methodical educational complex corresponding to a standard curriculum and providing an opportunity for a student to master a course or its section independently or with the help of a teacher. Such a product is created with built-in structure, dictionaries, capabilities, and the like.

The use of computer technologies creates the prerequisites for the intensification of the entire educational process and makes it possible to widely use in practice psychological and pedagogical developments that ensure the transition from mechanical mastering of knowledge to mastering the ability to independently acquire new knowledge, contributes to the disclosure, storage and development of students' personal qualities.

In psychology, issues of mental development are multifaceted and have more than one line of research. The methodology of M. Montessori convinces of the need to develop motor skills that directly lead to the formation and development of basic mental functions, which at a certain stage of mental development cause the transition to a complex mental organization, the formation of higher mental functions associated with speech development (Mokhova, 2017).

Today's accountant requires deep professional knowledge and ability to creatively assess the production situation. Despite this, he must have developed managerial skills and possess management decision-making skills.

General provisions of the requirements for flexibility of EEMC should be adapted to the individual capabilities of the student, that is, to the student's knowledge and skills, as well as his psychological characteristics in the learning process. There are three levels of flexibility EEMC. The first level is the ability of students to study educational material in accordance with the individual pace, which is convenient for them. The second level is a diagnostic analysis of the student's condition, the results of which suggest the content and methods of training. The third level is based on a frank approach, which does not imply a grouping of users, and the authors recommend that students can create more options for all content as much as possible (Amirov, 2019: p.19).

The effectiveness of training in the technical school provides, inter alia, the use of social electronic networks, allowing to provide creative research activities of the teacher and students in the educational process. In addition, the use of electronic networks significantly increases the interest of students in independent work outside the classroom by "integrating teaching and learning materials into social networks".

In the conditions of development of modern society, the subject-information environment is actively expanding. "In other words, the educational environment is available if the student's needs are met (by adapting, replacing or changing the presentation of digital resources). Accessibility is determined by the flexibility of the educational environment (in terms of the methods of presentation and control, the structure, the method of access and support for the student) and the availability of content that is alternative in form but identical in content. User needs and preferences depend on the situation and environment, technical requirements for user devices, available tools (for example, assistive technologies such as Braille, playback devices, voice recognition systems, input tools), user experience or disability in the traditional sense" (Morozov, 2018). The amount of information goes beyond the textbooks of economics, financial accounting, the tax system, and the like. In economics classes, students work with sources (for example, decrees, applicable laws), in planning classes - electronic reference books (typical production standards, qualification reference books, etc.), Internet educational resources are used to search for the latest statistical data, newspaper and magazine articles, television programs (Zagrebina, 2015).

Such classes require printing a large number of materials. In the case of work on the Internet, this need disappears while students search for information directly in the document itself, while at the same time studying its structure and features. During the lesson, they work in groups, process the information received. It is in the course of such work that information competence is being formed. The use of these forms of work allows not only to create conditions for saving time, but also to carry out work to stimulate and develop the cognitive interest of students, to develop their skills in working with information (Ilyin, 2017).

In the application of e-learning resources, the organization of group activities of students is important. "The 
specifics of the organization of formative assessment in group educational and professional activities of students is today an urgent problem in the context of interaction between subjects of different cultures, finding a joint solution to a problem situation, showing activity and making necessary changes in solving a problem and reflecting on educational achievements" (Sufiah, 2015: p. 92). For the organization of group activities of students to discuss economic situations that arise in their professional activities, multimedia presentations are used, educational films that reproduce certain processes in the form of real special surveys, electronic and multimedia textbooks are used (Kochisov, 2015).

In the educational activities of the teacher, social networks are used to solve the following tasks:

- collectively organize the work of students on a pair (and outside the classroom), which contributes to the community, gaining experience in a team;

- to expand the organization of student learning at home, as they allow the use of learning content at any time of the day, not limited to the time frame;

- $\quad$ to promote self-study students, because each student must work in their own rhythm;

- informal communication between the teacher and the student;

- change the role of the teacher - he will cease to be just a teacher, will become an assistant, friend, mentor;

In addition, social networks:

- familiar environment for students;

- it's free. You will not need enough money to purchase expensive data storage software;

- social networks have very good functionality, which allows you to quickly share important information with students;

- the most visited. That is, the main user of social networks are students, that is, the audience from 16-19 and from 20-29 years old, who use the Internet most of all. If students go to educational sites only when necessary, they spend most of their time on social networks;

- $\quad$ using social networks, students master the search-analysis of information;

- increasing interest in the study of a particular discipline. After all, it is more interesting to search and master educational material not in printed form, but through the Internet;

- The educational process does not have to be interrupted at the time of illness of the student or teacher. You can carry it out and participate in it online;

- improving communication between students, cohesion of a group of students, gaining experience in self-organization of their work away from the audience and the process participant.

So, professional training should be aimed at the formation of an active subject of activity capable of self-education, to independently acquire knowledge, knowledgeable in the areas of use and application of the obtained data for the purpose of personal development and self-improvement (2; five; 6).

There are the following fundamentally important areas of use of e-learning resources in the educational process:

- $\quad$ source of educational information;

- tool in the development of educational material;

- a motivational tool in the organization of educational activities;

- $\quad$ an objective way to exercise control, self-control, level of learning material mastering;

- a tool for creating creative projects;

- $\quad$ an effective tool for career guidance work;

- tool when conducting virtual tours. 


\section{CONCLUSION}

Thus, taking into account the above, the development and use of EER can distinguish a number of requirements that affect their effectiveness in practical use.

1. The EER should be built taking into account the peculiarities of such cognitive mental processes as perception (mainly visual, as well as auditory and tactile), attention (its stability, concentration, switching, distribution and volume), thinking (theoretical conceptual, theoretical figurative, practical clearly -shaped, practical visual-effective), imagination, memory (instant, short-term, operational, long-term, the phenomenon of information substitution in short-term memory).

2. The presentation of educational material EER should be built on the basis of the system of students' knowledge, including knowledge of the language, should be understandable to them, but not too simple, since this may lead to a decrease in attention.

3. The EER should be directed to the development of both figurative and logical thinking.

The key concept of education based on the use of EER potential is the term "information". There is still no precise definition of this term, but in order to form the EER architecture, it should be clarified. Under the information in the future, we will understand a certain set of information that changes the uncertainty in our ideas about the world, society or person.

The development of electronic teaching materials and their use in the educational process is an important means of improving the methodological, informational, communicative, professional competence of future specialists.

\section{BIBLIOGRAPHIC REFERENCES}

Amirov N.I., \& Ruziboev U. (2019) Necessary requirements for modern electronic educational resources. Pedagogy and modern education: traditions, experience and innovations. Collection of articles of the VI International Scientific Practical Conference. pp. 18-20.

Grachikova Yu.V. (2016). Requirements for the electronic educational resource of the game type when teaching mathematics. Problems of modern pedagogical education. 2016.N52-4. Pp. 45-52.

Ibatova, A. Z., \& Mukhametgaliyev, I. G. (2018). New ways of professional language thesaurus formation among students of engineering specialties. XLinguae, 11(4), 22-31. doi:10.18355/XL.2018.11.04.03

Ilyin A.G. (2015). The main difficulties of introducing practice-oriented teaching of cultural studies in a modern pedagogical university. Internet journal Naukovedenie. Vol. 7. No. 2 (27). P. 136.

Ilyin A.G. (2017). Philosophy in the Information Society and Education. University in the global world: new status and mission, collection of materials of the XI International Scientific Conference. Moscow State University Lomonosov, Sociological Faculty. p. 100-102.

Ilyin, A., \& Ibatova, A. (2017). Orientation of the modern educational process on the concept of truth. 4 (2).

Ivygina A., Pupysheva E., \& Mukhametshina D. (2018). The basic general education level. Journal of Social Research Education. 2018. Vol. 9. No. 2. S. 160-171.

Khafizova N.Yu. (2018). Electronic educational resources as a tool to improve the level of professionalism of teachers in the conditions of additional professional education. Innovative projects and programs in education. N6. S. 74-77.

Kochisov V.K., Gogitsaeva O.U., \& Timoshkina N.V. (2015). Electronic educational resource as a new pedagogical tool in the context of the development of interdisciplinary connections. Educational technologies and society. Vol. 18. No. 4. P. 613-628.

Korolev D.A., Bulatov A.A., \& Komkov R.V. (2013). Electronic educational resources of the new generation . Scientific and technical libraries. No. 8. P. 35-38.

Krivolapova E.V. (2019). Electronic educational resources as a means of improving the quality of education at the university. University complex as a regional center for education, science and culture Materials of the All-Russian Scientific and Methodological Conference. pp. 3198-3200.

Levin, M.V., \& Sosenushkin, S.E. (2015). Standardization of requirements for electronic educational resources, taking into account individual needs and preferences of students. Open Education. N1 (108). Pp. 33-36.

Mokhova S.Yu. (2017). On the issue of psychological requirements for an electronic educational resource. News of the Irkutsk State University. Series: Psychology. V. 19. S. 67-73.

Morozov A.V., \& Samborska L.N. (2018). Electronic educational resources for children with disabilities in the system of national education. Electronic resources in continuing education works of the VII International Scientific and Methodological Symposium. 
pp. 103-106.

Stepanova T.Yu., \& Esmurzaeva ZH.B. (2015). Electronic educational resource as a means of increasing students' cognitive activity . Omsk Scientific Herald. N5 (142). Pp. 86-88.

Sufiah R. (2015). Group activity of students as a form of organization of formative assessment. Teacher XXI century. N1-1. Pp. 90-95.

Vasiliev V.L., \& Gapsalamov A.R. (2017). Improving human resource planning in the modern economy of the Russian Federation. Bulletin of the Samara State University of Economics. No. 2 (148). Pp. 80-87.

Zagrebina S.A. (2015). Interactive video as an electronic educational resource in the teaching of cultural disciplines at the university . Electronic information and educational environment of the university: problems of formation, contextual filling and functioning of the IV All-Russian Methodical Conference by ed. E.A. Khodyrevoy. p. 67-71.

How to cite this article: Meteleva, L. A., Shankar, K., \& Ayshwarya, B. (2020). Electronic educational resources in the process training. Religación. Revista De Ciencias Sociales Y Humanidades, 5(23), 90-95. Retrieved from http://revista.religacion.com/ index.php/religacion/article/view/601

Submitted: 15 November 2019 Accepted: 19 February 2020 Published: 31 March 2020

Religación. Revistais de Ciencias Sociales y Humanidades is a peer-reviewed open access journal published by CICSH-AL Centro de Investigaciones en Ciencias Sociales y Humanidades desde América Latina |Religación| 